\title{
ANALISA POTENSI UNTUK PENGEMBANGAN INDUSTRI KULIT DI GUNUNG PUNTANG KABUPATEN BANDUNG
}

\author{
DIAN KURNIANINGRUM, ISTON DWIJA UTAMA, \\ NUR AZMI KARIM, DAN CHYNTIA IKA RATNAPURI \\ STTK BINUS, Bandung
}

\begin{abstract}
Gunung Puntang in Bandung Regency West Java is known as one of a coffee and vegetable producer. Moreover, it is also wellknown as a leather craft industry center in West Java. Research entitled "Potential Analysis to Development Leather Industry in Gunung Puntang, Bandung Regency" is an initial research that will become a basis for further research. Short-term goal of this research is to figure out the leather industry potential in villages which located in Mount Puntang. So in the future, researchers could develop effective strategies for those areas. This research use external and internal factors analysis to conclude the opportunities, threaths, strengths and weaknesses of the industry, in order to solve the research questions. As a long-term goal, it hopes that this research result could increase village GDP and achieve community welfare.
\end{abstract}

Keywords: Potential Analysis, Leather Industry, Eksternal Analysis, Internal Analysis 


\section{PENDAHULUAN}

Dalam suatu sistem perekonomian, salah satu indikator tercapainya tujuan perekonomian adalah pendapatan perkapita masyarakat yang tinggi. Pendapatan perkapita dihitung dengan cara membandingkan PDB (Produk Domestik Bruto) dengan jumlah penduduk di suatu daerah. Saat ini kesenjangan antara pendapatan perkapita kota dengan desa dinilai cukup tinggi, karenanya terjadi urbanisasi. Untuk mengurangi gap tersebut dan menghindari terjadinya urbanisasi maka potensi usaha dari desa harus dimaksimalkan.

Gunung Puntang di kabupaten Bandung dikenal sebagai salah satu destinasi wisata bagi mereka yang senang berkemah di alam terbuka. Desa-desa di daerah Gunung Puntang dikenal sebagai penghasil kopi dan sayuran. Berdasarkan informasi dari aparat desa, diketahui mata pencaharian sebagian besar penduduk desa adalah sebagai wirausaha, petani, dan buruh.

Desa-desa tersebut juga memiliki potensi lain yang belum diketahui oleh banyak orang. Desa Campaka Mulya di Gunung Puntang memiliki sentra kerajinan kulit. Produk yang dihasilkan sebagian besar adalah sepatu kulit, baik untuk pria maupun wanita. Beberapa pengrajin kulit di desa tersebut bekerja secara mandiri sebagai pelaku industri kreatif. Mereka sudah memiliki pasar dan merk, walaupun omset penjualannya masih terbatas. Pengrajin kulit lainnya memilih untuk memberikan jasa maklun dikarenakan terbatasnya dana dan koneksi yang mereka miliki.

Menimbang dari hasil pengamatan di atas, peneliti tertarik untuk mengembangkan industri kulit yang ada di Gunung Puntang. Namun sebelum merumuskan program pengembangan yang tepat, peneliti harus memahami terlebih dahulu kelebihan, kekurangan, peluang dan faktor-faktor penghambat yang bisa mempengaruhi potensi dari industri kulit di Gunung Puntang tersebut.

Penelitian ini merupakan penelitan awal yang akan dijadikan pijakan bagi penelitian selanjutnya. Hasil akhir yang diharapkan dari penelitian ini adalah peneliti dapat memahami kondisi usaha saat ini dan potensi-potensi yang dapat dikembangkan dari industri kulit di Desa Campaka Mulya Kecamatan Banjar Kabupaten Bandung.
Kemudian penelitian ini akan dilanjutkan dengan penelitian lain yang bertujuan untuk memaksimalkan potensi yang dimiliki oleh pengrajin kulit di Desa Pasirmulya. Sehingga dalam jangka panjang diharapkan industri kulit akan berkembang dan mampu menaikkan PDB serta memajukan pembangunan di daerah tersebut.

\section{TINJAUAN PUSTAKA}

Sebagaimana telah dijelaskan sebelumnya dalam rangka memeratakan pembangunan dan mencegah terjadinya urbanisasi kita dituntut untuk memaksimumkan potensi yang dimiliki oleh desa. Untuk dapat memaksimumkan potensi desa, kita harus membantu desa dalam merumuskan strategi pengembangan yang tepat. Fred R. David (2015) mengusulkan sebuah model komprehensif yang dapat digunakan untuk merumuskan startegi (Gambar 1).

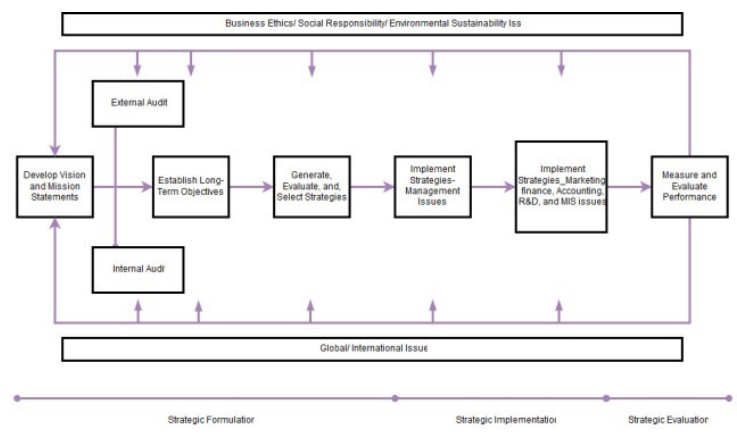

Gambar 1. Model Perumusan Stategi

Sumber: Strategic Management Concepts and Cases, Fred R. David 15 th edition 2015

Langkah pertama yang harus dilakukan perusahaan adalah menentukan visi dan misi dari perusahaan. Kemudian kondisi eksternal dan internal yang akan mempengaruhi tercapainya visi dan misi perusahaan tersebut, dianalisis sehingga bisa dipahami peluang, hambatan, kekuatan dan kelemahan yang dimiliki dan dihadapi oleh perusahaan. Dari hasil analisis kondisi ekternal dan internal, perusahaan bisa menetapkan objektif atau tujuan jangka pendek perusahaan yang akan mendukung tercapainya visi dan misi. Untuk mencapai objektif tersebut, perusahaan harus merumuskan strategi yang kemudian dilaksanakan dan di evaluasi. Dari hasil evaluasi dapat diketahui efek- 
tifitas dari strategi tersebut.

Fred R. David (2015) membagi pengaruh inti (key forces) yang berasal dari eksternal perusahaan menjadi 5 kategori: pertama adalah pengaruh ekonomi (economic forces).Kedua adalah sosial, budaya, demografi, dan pengaruh natural dari lingkungan sekitar (social, cultural, demographic, dan environment natural forces). Ketiga adalah politik, legalitas, dan peran pemerintah (politic, legal, and government forces). Keempat adalah pengaruh teknologi (technology forces), dan terakhir adalah pengaruh dari persaingan (competitive forces).

Dari hasil informasi yang dapat dikumpulkan tentang pengaruh eksternal yang akan mempengaruhi perusahaan, dapat ditentukan peluang dan ancaman yang dihadapi oleh organisasi. Informasi tersebut bisa didapatkan dari pesaing (competitors), pemasok (suppliers), distributor (distributors), dan dari sumber-sumber lainnya.

Fred R. David (2015) juga mengungkapkan informasi faktor internal yang mempengaruhi perusahaan bisa dianalisis dari kegiatan inti perusahaan yaitu manajemen, pemasaran, keuangan, produksi/operasional, penelitian dan pengembangan, serta sistem informasi manajemen. Analisis terhadap kegiatan inti perusahaan tersebut, bisa memberikan informasi tentang tingkat kesehatan dari suatu organisasi, sehingga bisa diketahui kekuatan dan kelebihan dari organisasi. Gambar 2.2 merangkum hubungan antara faktor-faktor tersebut di atas dengan organisasi.

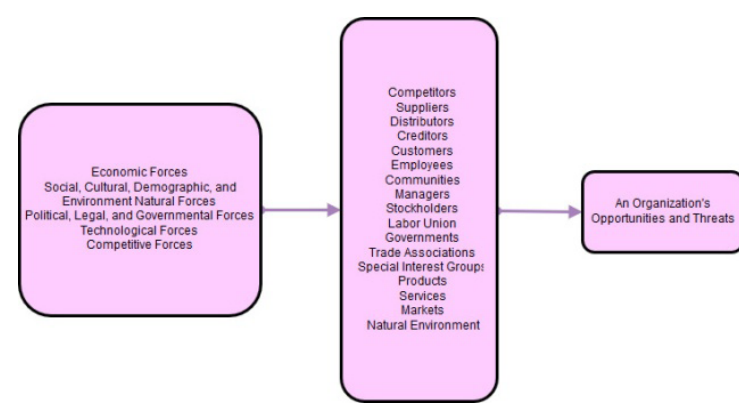

Gambar 2. Hubungan Antara Faktor Eksternal dengan Organisasi

Sumber: Strategic Management Concepts and Cases, Fred R. David 15 th edition 2015

Tujuan jangka panjang yang diharapkan dari penelitian ini adalah memaksimalkan pendapatan desa sehingga tercapai kesejahteraan dan pemerataan pembangunan bagi seluruh penduduk. Sebelum merumuskan strategi yang dirasa paling tepat untuk mencapai tujuan tersebut, maka perlu dilakukan analisis internal dan eksternal dari kondisi saat ini. Sehingga bisa dipahami potensi potensi yang paling memungkin untuk dikembangkan.

Sebagaimana telah dijelaskan sebelumnya, salah satu produk industri dari Desa Cempaka Mulya adalah kerajinan dari kulit. Peneliti menimbang bahwa masih banyak potensi-potensi yang dapat dikembangkan dari industri kulit di desa tersebut. Peneliti menggunakan analisis kondisi internal dan eksternal dari usaha untuk mencari potensi industri kulit yang paling mungkin untuk dikembangkan di Gunung Puntang. Kerangka pikiran dari penelitian ini tergambar pd gambar 3 .

Beberapa penelitian sebelumnya, dengan topik yang serupa dengan penelitian ini juga menggunakan analisis kondisi ekternal dan internal untuk mencapai tujuan penelitian. Nurdin Hidayat dan I Ketut R. Sudiarditha (2007) menggunakan analisis kondisi internal dan eksternal untuk memahami potensi pengembangan industri meubel rotan di Halim Perdana Kusuma Jakarta Timur.

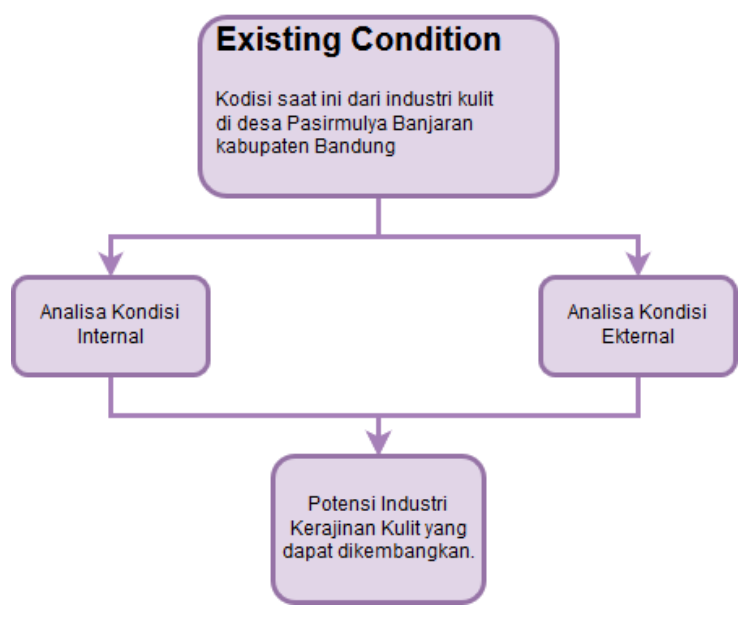

Gambar 3. Kerangka Penelitian

Sumber: Diolah berdasarkan model Fred.R. David (2015)

Peneliti lainnya Reza M. Zulkarnaen (2016) meneliti pengembangan potensi ekonomi desa melalui badan usaha milik desa (BUMDES) di Desa Parakan Salam Purwakarta. Dari hasil analisis kondisi internal dan ekternal yang telah dilaku- 
kan, disimpulkan perlu adanya BUMDES untuk membantu peningkatan perekonomian desa.

Hidesuke Tanaka (2009) menggunakan analisis internal dan eksternal untuk menganalisa hubungan kekuatan industri, orientasi market, dan kemampuan bisnis terhadap performa dari perusahaan.

Sofyan Indris (2015) menggunakan analisis eksternal dan internal untuk menganalisa performance pengusaha kecil di Indonesia.

Heather C. Banham (2010) menggunakan "The Degrees of Turbulance Model" untuk menganalisa perubahan lingkungan eksternal untuk memastikan kelangsungan usaha dari pengusaha kecil menengah.

\section{METODE PENELITIAN}

Penelitian menggunakan pendekatan qualitative research dan metode exploratory research. Teknik ini sesuai apabila digunakan pada penelitian tahap awal untuk melihat permasalahan atau fenomena umum yang sering terjadi (Earl, 2009). Penelitian exploratory dilakukan dengan tiga tujuan (Earl, 2009), yakni:

1. Untuk memuaskan rasa keingintahuan peneliti serta untuk pemahaman yang lebih baik.

2. Untuk menguji kelayakan yang akan digunakan untuk penelitian selanjutnya.

3. Untuk mengembangkan metode yang akan digunakan pada penelitian selanjutnya.

Faktor-faktor yang dapat digunakan untuk menganalisis manajemen strategis suatu usaha dengan skala mikro, kecil, dan menengah adalah sebagai berikut (Covin, 1989):

1. Kondisi lingkungan eksternal, termasuk tingkat persaingan

2. Struktur organisasi

3. Strategic posture perusahaan

4. Kinerja keuangan perusahaan

Sementara Herri dan Wafa (2004) melakukan analisis terhadap faktor internal dan faktor eksternal yang dapat mempengaruhi kinerja suatu usaha kecil dan menengah, faktor internal tersebut adalah sikap entrepreneurship (fleksibel, berani mengambil risiko, proaktif, dan innovatif), strategi, dan struktur organisasi. Sedangkan pada faktor eksternal, variabel yang diteliti Antara lain adalah kebijakan pemerintah, kondisi pasar, dan tingkat kompetisi.

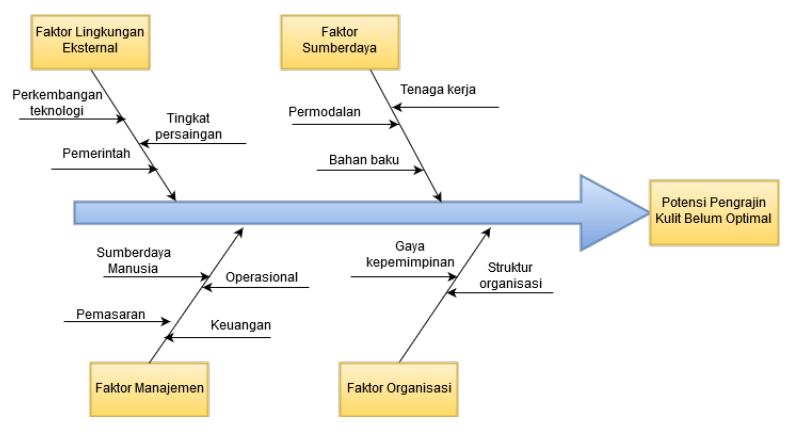

Gambar 4. Fishbone Diagram Penelitian

Sumber: hasil pengolahan peneliti

Penelitian lain yang dilakukan oleh Grisna dan Qaanita (2013) dengan mengambil variabel aspek kewirausahaan (motivasi, optimisme, efektivitas, self-management), kompetensi sumberdaya manusia (keterampilan, kemampuan, pengetahuan), inovasi (kreativitas produk/jasa, teknologi), dan sustainability (pertumbuhan dan profitabilitas) untuk mengukur kinerja usaha kecil dan menengah.

Penelitian sejenis terhadap analisis faktor kondisi lingkungan internal dan eksternal pada usaha kecil dan menengah di Indonesia juga dilakukan oleh Idris dan Primiana (2015) dengan mengambil variabel internal antara lain seperti aspek sumberdaya manusia (pemilik, manajer, dan pegawai), aspek keungan, aspek teknis dari produksi, dan aspek pemasaran, variabel eksternal yang diambil antara lain seperti kebijakan pemerintah, aspek social budaya, aspek perekonomian, persaingan industri, dan pesaing.

Berdasarkan beberapa penelitian tersebut, Gambar 4 menggambarkan fishbone diagram dari penelitian ini yang kami adopsi dan sesuaikan untuk tujuan penelitian.Faktor yang kami akan analisis adalah sebagai berikut:

1. Faktor lingkungan eksternal.

Faktor ini terdiri dari perkembangan teknologi, pemerintah, dan tingkat persaingan. Dalam hal teknologi, perlu dianalisis tentang teknologi yang tepat guna serta dapat di implementasikan oleh para pengrajin kulit disana. Analisis peran dari pemerintah terutama pemerintah Kabupaten Bandung juga akan diamati dan dipelajari 
agar mendapatkan informasi dan kontribusi dari pemerintah terhadap para pengrajin kulit. Faktor tingkat persaingan akan mengukur persaingan pada sektor industri kulit serta strategi dan hal apa saja yang telah dilakukan oleh pesaing tersebut.

2. Faktor sumberdaya.

Faktor tenaga kerja yang akan dianalisis adalah dengan mengamati kondisi tenaga kerja saat ini seperti keterampilan dan keahlian yang dimiliki serta wawasan untuk mengembangkan produk. Faktor bahan baku lebih menitikberatkan pada ketersediaan bahan baku dan juga kualitas dari bahan baku yang dimiliki oleh pengrajin. Faktor permodalan akan mengamati kemudahan para pengrajin kulit untuk mendapatkan bantuan permodalan ataupun bantuan dalam bentuk lainnya dari pihak ketiga.

3. Faktor manajemen.

Faktor manajemen lebih menitikberatkan pada mapping kondisi saat ini yang terjadi pada internal perusahaan seperti aspek sumberdaya manusia yang dimiliki seperti jumlah tenaga kerja serta keahlian dan keterampilan, aspek pemasaran seperti jangkauan produk serta kualitas dan harga jual, aspek keuangan seperti struktur permodalan dan laporan keuangan, dan aspek operasional seperti proses bisnis yang ada didalam perusahaan.

4. Faktor organisasi.

Faktor ini lebih menekankan pada analisis bentuk organisasi dan juga gaya kepemimpinan manajer atau pemilik perusahaan dalam mengelola perusahaannya.

Menurut Sekaran dan Bougie (2013), data dapat dibedakan menjadi dua jenis, yakni data primer dan data sekunder. Data primer adalah informasi yang diperoleh dari sumber data pertama di lokasi penelitian atau obyek penelitian untuk tujuan penelitian (Sekaran dan Bougie 2013). Data sekunder adalah informasi yang diperoleh melalui sumber data yang telah tersedia sebelumnya (Sekaran dan Bougie 2013).

Data primer akan diperoleh dari hasil kunjungan dan survey para pengrajin kulit yang akan dijadikan responden dengan metode interview. Data sekunder dapat diperoleh dari buku textbook atau jurnal yang berkaitan dengan permasalahan penelitian.

Menurut Sekaran dan Bougie (2013) data da- pat dikumpulkan melalui beberapa cara, pengaturan lokasi studi - lapangan atau lab, serta studi pustaka. Pada penelitian ini akan digunakan beberapa teknik pengumpulan data yakni:

\section{Wawancara.}

Tujuan dari wawancara adalah untuk mendapatkan informasi sesuai dengan isu yang menjadi perhatian dalam penelitian, selain itu teknik ini juga cocok apabila diterapkan pada tahap studi $e k$ sploratory (Sekaran dan Bougie, 2013). Wawancara dapat dilakukan dengan unstructured atau structured interview (Sekaran dan Bougie, 2013), untuk penelitian ini peneliti akan menggunakan unstructured interview, dimana peneliti akan menggali informasi awal sesuai dengan jawabanjawaban yang diberikan oleh responden untuk kemudian akan digali lebih dalam lagi sesuai dengan kebutuhan penelitian.

2. Studi Pustaka.

Peneliti akan mengambil informasi dari textbook, jurnal, artikel, maupun dari internet yang relevan dengan penelitian guna menganalisis dan mendeskripsikan masalah.

\section{HASIL DAN PEMBAHASAN}

Kunjungan ke Desa Campaka Mulya di Kecamatan Cimaung Kabupaten Bandung telah dilaksanakan pada tanggal 18 Januari 2018 dan 20 Maret 2018. Pada kunjungan tersebut peneliti telah melakukan survey dan observasi mengenai kondisi pengrajin kulit di Gunung Puntang Bandung.

Sebagian besar Industri kulit di Gunung Puntang tersebar di Desa Campaka Mulya, sekitar Jalan Raya Gunung Puntang km 20-30. Kita bisa menemui 5 hingga 10 pabrik kulit di area tersebut.

Berdasarkan diagram Fishbone dari penelitian, analisa kondisi eksternal menitikberatkan pada kondisi lingkungan eksternal dan faktor sumber daya. Sedangkan analisa kondisi internal menitikberatkan pada manajemen dan faktor organisasi dari perusahaan.

Berdasarkan kodisi lingkungan eksternal, ada beberapa factor yang dianalisa yaitu perkembangan teknologi, tingkat persaingan, dan pemerintah.

Dari sisi teknologi, hingga saat ini pemesanan produk masih mengandalkan telepon dan pesan menggunakan aplikasi. Pengrajin belum berani 
memasarkan produknya secara online dikarenakan kurangnya kapasitas produksi dari usaha mereka. Sehingga dikhawatirkan tidak mampu memenuhi pesanan pelanggan.

Proses pembuatan sepatu masih dikerjakan dengan tangan dan teknologi sederhana, tidak menggunakan mesin berteknologi tinggi.

Pesaing utama pengrajin kulit Gunung Puntang adalah pengrajin kulit dari Garut. Gunung Puntang secara geografis terletak tidak jauh dari kota Bandung. Akses jalan antar kota juga cukup memadai. Oleh sebab itu penjualan kerajinan kulit dari Gunung Puntang ke kota Bandung memiliki daya saing yang lebih baik, karena pengrajin bisa menawarkan biaya transportasi yang lebih rendah.

Dari sisi pemerintah, pemerintah daerah kabupaten Bandung membantu pemasaran pengrajin dengan mengadakan pameran, hanya para pengrajin merasa hingga saat ini bantuan pemerintah terhadap pengrajin kulit di Gunung Puntang belum maksimal dikarenakan kalah pamor dengan produk kopi Gunung Puntang.

Faktor-faktor sumber daya yang dianalisa meliputi faktor tenaga kerja, modal, dan bahan baku. Kelebihan yang dimiliki oleh pengrajin dari sisi tenaga kerja adalah tersedianya cukup tenaga kerja manusia di desa. Sebagian besar tenaga kerja adalah wanita dikarenakan banyak penduduk pria di desa tersebut bekerja di kota.

Potensi lain yang berhubungan dengan sumber daya dan menjadi kelebihan dari pengrajin adalah tersedianya lahan yang cukup luas yang dapat digunakan untuk memproduksi produk industri kerajinan.

Pengrajin kulit di Gunung Puntang Kabupaten Bandung mengeluhkan beberapa masalah yang mereka hadapai. Masalah utama yang dihadapi pengrajin adalah masalah modal. Karena kurangnya modal mereka menghadapi masalah kekurangan cash flow. Mereka harus meminta down payment yang cukup besar kepada pemesan (minimal 50\%) untuk menutupi ongkos produksi. Hal tersebut bisa mengakibatkan pesanan berpindah kepada pengrajin lain yang dapat memberikan persentase down payment yang lebih rendah.

Dari sisi bahan baku, hingga saat ini pasokan kulit cukup terjamin, dikarenakan cukup banyak penduduk desa yang beternak sapi dan kambing.
Analisa dari sisi manajemen menitikberatkan pada kualitas sumber daya manusia, pemasaran, operasional dan keuangan perusahaan. Dari sisi kualitas sumberdaya manusia, para pengrajin menjelaskan bahwa jumlah tenaga kerja terampil yang mereka miliki tidak banyak. Sebagian besar pekerja yang mereka miliki hanya mampu mengerjakan pekerjaan yang tidak memerlukan keterampilan khusus.

Kegiatan pemasaran produk dan pelayanan pelanggan dilakukan sendiri oleh pemilik dan pegawai terpecayanya. Sebagian pembeli produk kulit mereka adalah pedagang barang kulit di kota Bandung terutama daerah Cibaduyut. Para pengrajin rata-rata memiliki pelanggan inti yang membeli barang dalam jumlah besar. Hal tersebut berperan besar pada kelangsungan usaha pengrajin. Menurut para pengrajin biaya pokok produksi untuk produk yang dipesan dalam jumlah banyak sama besar dengan biaya pokok produksi produk yang dipesan oleh konsumen individu.. Masalah kapasitas produksi dan modal menghalangi pesaing untuk menjual produk langsung kepada enduser.

Operasinal produksi dilakukan secara sederhana. Mereka telah memiliki mesin namun jumlahnya terbatas. Alat-alat yang digunakan sebagian besar pengrajin sepatu antara lain cetakan kaki kayu, mesin seset, tang jepit, palu, paku, kompor, mesin gerindra, pisau seset, dan mesin jahit.

Masalah operasional lain yang dihadapi pengrajin selain terbatasnya kapasitas produksi adalah, masih terbatasnya jumlah model produk terutama sepatu yang bisa diproduksi. Terbatasnya jumlah model yang diproduksi dikarenakan terbatasnya kemampuan teknisi pembuat produk dan terbatasnya peralatan. Saat ini sebagian besar produk yang diproduksi adalah sepatu boot yang biasa digunakan oleh militer.

Beberapa produk kulit lain yang dihasilkan adalah dompet dan sarung tangan. Sebagian besar pengrajin telah memiliki merk produk tersendiri, walaupun belum didaftarkan.

Sebagian besar pengrajin kulit di Gunung Puntang belum melakukan pengelolaan dan pencatatan keuangan dengan baik. Mereka hanya memiliki catatan pembelian dan penjualan barang, catatan hutang dan piutang, saldo tabungan, dan 


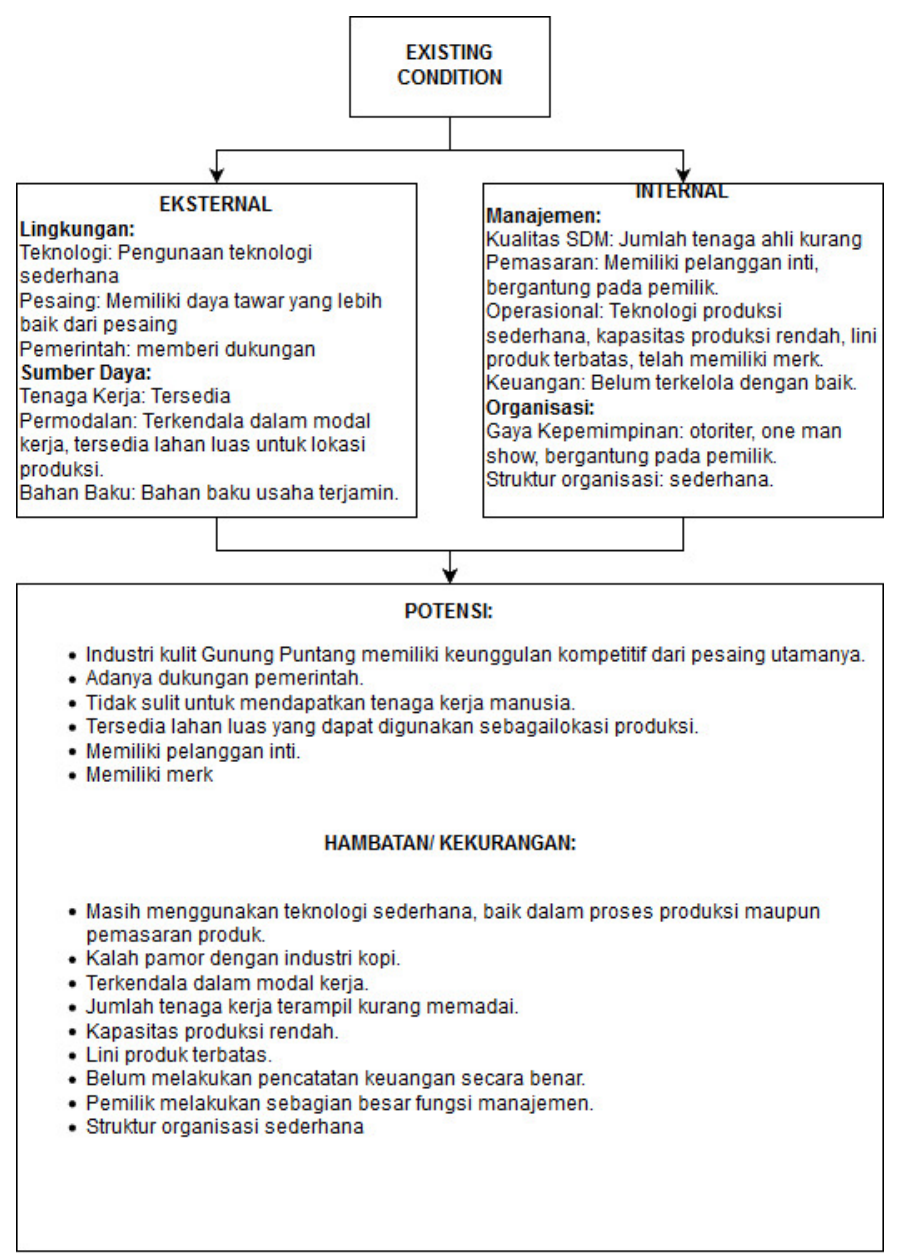

Gambar 5. Potensi Industri Kulit Di Gunung Puntang

Sumber: Hasil analisa penelitian

beberapa memiliki catatan pengeluaran biaya. banyak divisi. Biasanya hanya terbagi dua yaitu Para pengrajin tidak mengetahui secara pasti besar keuntungan yang dihasilkan pada suatu periode. Informasi yang bisa dikumpulkan hanya omset penjualan, besar tagihan, besar hutang, nilai pembelian barang, persentase keuntungan yang mereka peroleh dari setiap penjualan, dan uang kas yang mereka miliki saat ini.

Dari sisi organisasi, gaya kepemimpinan dan struktur organisasi dari industri kulit di Gunung Puntang menjadi faktor-faktor yang dianalisa. Sebagian besar pemilik industri kerajinan adalah pemimpin dari perusahaan. Beberapa industri sudah berbentuk $\mathrm{CV}$, namun sebagian besar masih berbentuk perusahaan perorangan. Gaya kepemimpinan mereka sebagian besar adalah otoliter. Pemilik melakukan beberapa pekerjaan sekaligus. Mereka berperan sebagai "one man show". Struktur organisasi yang dimiliki para pengrajin pemimpin dan bagian operasional.

\section{KESIMPULAN}

Berdasarkan uraian di atas bisa disimpulkan potensi yang dimiliki oleh industri kulit di Gunung Puntang adalah sebagai berikut:

1. Industri kulit Gunung Puntang memiliki keunggulan kompetitif dari pesaing utamanya.

2. Adanya dukungan pemerintah.

3. Tidak sulit untuk mendapatkan tenaga kerja manusia.

4. Tersedia lahan luas yang dapat digunakan sebagai lokasi produksi.

5. Memiliki pelanggan inti

6. Memiliki merk.

7. Sebagian besar pengrajin telah memiliki bentuk perusahaan baik perorangan atau $\mathrm{CV}$. pun tergolong sederhana. Mereka tidak memiliki 


\section{HAMBATAN}

Sedangkan hambatan dan kelemahan yang dimiliki oleh industri kerajinan kulit di Gunung Puntang adalah sebagai berikut:

1. Masih menggunakan teknologi sederhana, baik dalam proses produksi maupun pemasaran produk.

2. Kalah pamor dengan industri kopi.

3. Terkendala dalam modal kerja.

4. Jumlah tenaga kerja terampil kurang memadai.

5. Kapasitas produksi rendah.

6. Lini produk terbatas.

7. Belum melakukan pencatatan keuangan secara benar.

8. Pemilik melakukan sebagian besar fungsi manajemen.

9. Struktur organisasi sederhana.

\section{PENUTUP}

Urbanisasi adalah masalah yang dihadapi banyak negara, terutama negara berkembang. Timpangnya pendapatan penduduk kota dengan desa mengakibatkan banyak penduduk desa memutuskan untuk merantau ke kota. Tidak hanya itu kurangnya lapangan pekerjaan juga menyebabkan penduduk memutuskan untuk pindah ke kota.

Gunung Puntang berlokasi di Kabupaten Bandung, lokasinya tidak terlalu jauh dari kota Bandung. Desa yang berada di sekitar Gunung Puntang juga menghadapi masalah urbanisasi. Desa-desa tersebut pada dasarnya memiliki banyak potensi yang bisa dikembangkan. Salah satunya adalah industri kerajinan kulit.

Melalui penelitian ini peneliti ingin memahami kondisi eksternal dan internal yang mempengaruhi perkembangan industri kulit di Gunung Puntang. Gambar 5 menggambarkan kesimpulan dari hasil penelitian. Industri kerajinan kulit di Gunung Puntang memiliki beberapa potensi yang dapat dikembangkan mengingat industri tersebut memiliki keunggulan kompetitif dibandingkan pesaingnya, mendapat dukungan pemerintah, tersedianya lahan dan sumber daya manusia, memiliki pelanggan inti dan merk.

Diharapkan ke depannya penelitian ini dapat digunakan untuk menetapkan strategi yang paling tepat yang dapat digunakan untuk memajukan industri di wilayah desa dan mengurangi arus urbanisasi ke kota. 


\section{REFERENSI}

Anggadwita, Grisna dan Qaanita Yuuha Mustafid. (2013). Identification of Factors Influencing the Performance of Small Medium Enterprises (SMES). Procedia - Social and Behavioral Sciences, 115, 415-423. ISSN 8: 1877-0428.

Babbie, Earl.(2009).The Basic of Social Research. $5^{\text {th }}$ Edition. Cengage Learning. United States. ISBN 13: 978-0-495-81224-1.

Banham, Heather C. (2010). External Environmental Analysis For Small and Medium Enterprises (SMEs). Journal of Business \& Economics Research. 8(10). 19-26.

Covin, J. and D. Slevin.(1989). Strategic Management of Small Firms in Hostile and Begining Environments. Strategic Management Journal, 10, 75-87.

David, Fred R. dan Forest R. David. (2015). Strategic management: concepts and cases. $15^{\text {th }}$ edition. New Jersey: Prentice Hall.ISBN-13: 9780133768763

Herri and Wafa. (2004). The Influence of Internal and External Factors to The Performance of Indonesian Small and Medium Enterprises. Diambil dari: https://icsb.org/wp-content/uploads/2017/07/ icsb2004.pdf. Akses pada tanggal 24 Januari 2018.

Hidayat, Nurdin., I Ketut R. Sudiarditha. (2007). Analisa Potensi Pengembangan Industri Kecil Pada Usaha Meubel Rotan Halim Perdana Kusuma Jakarta Timur. Jurnal Ilmiah Econosains. 5(1). 52-66.

Idris, Sofyan, Ina Primania. (2015). Internal and External Environment Analysis on The Performance of Small Medium Enterprises (SMEs) In Indonesia. International Journal of Scientific \& Technology Research, 4. ISSN 8: 2277-8616.

Sekaran, Uma dan Roger Bougie. (2013). Research Methods For Business: A Skill Building Approach. $6^{\text {th }}$ Edition. John Wiley \& Sons Ltd. United Kingdom. ISBN 13: 978-1-119-94225-2.

Tanaka, Hidesuke. (2009). Effects of Industry Forces, Market Orientatition, Market Capabilities on Business Performance: An Empirical Analysis of Japanese Manufacturers from 2009 to 2011. Journal of Business Research. 69(12). 5611-5619.

Zulkarnaen, Reza M. (2016). Pengembangan Potensi Ekonomi Desa Melalui Badan Usaha Milik Desa (BUMDES) Pondok Salam Kabupaten Purwakarta. Jurnal Aplikasi Ipteks untuk Masyarakat. 5(1). 1-4. 
